\title{
ECONOMICS
}

\section{State management of construction financial system in Ukraine}

\author{
V. V. Karpenko, O. S. Petrykiva \\ Kharkiv National University budivnitstva ta architecture, Ukraine \\ Corresponding author.E-mail: karpenko.vlada1978@gmail.com, gnhoc1902@gmail.com
}

Paper received 26.05.20; Accepted for publication 16.06.20.

\section{https://doi.org/10.31174/SEND-HS2020-232VIII40-07}

\begin{abstract}
Legislative regulation of public finance construction processes and transparency of monetary policy are the basis of the country's stability. The article considers the areas of improving the legal levers of the organization of activities of business entities and financial control by all services to ensure the legal regulation of the economy. It is proved that the legalization of the economy, the stability and efficiency of the country's banking system and the establishment of processes for the provision of state institutions to society public economic information on the formation and distribution of finance are the main criteria for national economic development in the global world structure. The strategy of creation of financial opportunities of infrastructure development, formation of the convenient environment for business activity of national commodity producers, considerable increase in cost of gross domestic product in Ukraine is defined.
\end{abstract}

Keywords: national financial system, state economy, legalization of the economy, budget revenues, enterprises of various forms of ownership, banking, income from taxes and fees, accumulation of capital, interprofessional coefficients, balance of entrepreneurship.

Introduction. State finances are the basis of any country's existence. Improving legislation to increase budget revenues is a priority for public authorities at all levels. It is necessary to emphasize the importance of studying, analyzing and controlling the processes of formation of economic information by society, the scientific community, specialists of industrial enterprises. The development of proposals for improving the formation of the country's finances and the distribution of monetary resources should be determined by all segments of the population for the formation of an efficient state economy. It is worth emphasizing that the main function of the state is national security and creating conditions for the development of all spheres of society.

Related Publications. The formation of the national financial system takes place in unstable globalization and domestic conditions. In the 1990s and 2000s, basic market institutions (open market economy, free prices, competition in markets, private property, contractual obligations) were formed in Ukraine, which replaced socialist institutions (state property, centralized directive planning, administrative pricing, foreign trade monopolies). But at the same time distorted norms of economic behavior were developed, which, in turn, encouraged corruption, shadowing, economic crime, legal nihilism, consumer fraud, quality manipulation, financial transactions, etc. [1, p.15]. Trends in financialization in the world are recognized as affecting the level of national security and stability of state economic systems. The regulation of the economy by the NBU led to the curtailment of budget financing of the national economy. Governments have mainly implemented measures aimed at stabilizing the development of the social sphere, and the opportunities for active use of effective fiscal instruments for the development of the real sector of the economy and the maintenance of economic growth have been significantly reduced. It is necessary to continue programs to limit the illegal economy, ensuring the transparency of operations with public financial assets [2, p.31]. In Ukraine the improvement of the current state of the consolidated budget (reducing its deficit and leading to a surplus) in 2015-2018 was ensured by increasing the tax burden on the economy and optimizing expenditures in health, educa- tion, basic and applied research, and also the reduction of expenditures on economic activity, which have the greatest impact on the development of the national economy and the formation of human capital [3, p.104]. In this regard, there is a need to improve the legislation on tax policy of the state, management of financial resources and informing the public about the movement of budget revenues and expenditures. Issues of making changes to the institutional structure of public finance management and deepening the transparency of budget operations were raised. In recent years, a number of conceptual government documents on public administration reform and public finances, local selfgovernment, as well as long-term development strategies have set tasks to ensure transparency of the budget process at the state and local levels [4, p.85]. Prerequisites for the introduction of an effective system of fiscal rules in Ukraine are: the presence of harmonized with international standards of statistical reporting of public finances, developed audit system, control of macrostabilization parameters of public finances in line with international standards of fiscal sustainability, which will bring public finance management tools closer to the best examples of world practice [5, p.53].

Results and its discussion. Today in the Ukrainian society the mechanisms of state finance management need legislative improvement and strengthening of control in budgetary policy. Improving state regulation of the economy is necessary in the areas of budget revenues - development of tax policy, creation of an effective banking system of the country, development of legal levers of formation of processes of functioning of personnel at the enterprises. The distribution of financial resources is coordinated on the minimum budget payments and the social sphere. Public economic information of state institutions limits the perception of factual data on the state economy by economic entities, communities, and citizens.

It is expedient to regulate the country's tax policy in the direction of legalizing the economy. Reforming the economic system has led to the creation of a significant number of enterprises of various forms of ownership - public and private, their organizational and legal forms. The result 
- there are trends of reduction of national production, expanding employment in the informal sector, there is a low level of wages, there are changes in the structure of employment by type of activity in the direction of reducing employment in manufacturing. Entrepreneurs hide real income. Ways to do this are different - the installation of unregistered registrars of settlement transactions (cash registers), overstatement of production costs in different ways. It is difficult to calculate even approximately how much money the state has lost on payments from income tax, value added tax, excise tax due to the concealment of real profits of enterprises. Here are the actual data on trends in economic activity of enterprises of different types. In 2018 there were almost 2 million enterprises in Ukraine. In this number: enterprises - legal entities $-19,4 \%$, individuals - entrepreneurs $-80,6 \%$. At the same time, $70,1 \%$ of people are employed at enterprises and $29,9 \%$ at sole proprietorships. At the same time, $84,5 \%$ of employees at enterprises and $15,5 \%$ of natural persons-entrepreneurs. The volume of produced and sold products (goods, works, services) for legal entities $-92,4 \%$, for private individuals $-7,6 \%$ [6]. With the reform of the economy the organizational and legal form of management was introduced individuals - entrepreneurs. Private individuals apply a simplified system of taxation, accounting and reporting, which provides for the payment of a single tax instead of a list of tax payments paid by enterprises in the general system of taxation. Most often individual entrepreneurs declare an amount of income that will be, in their opinion, optimal, which is only part of real income. At the same time legislators loyally regulate the activities of these businesses, arguing for the support of small businesses. Thus, this category of taxpayers hides their real revenues in huge amounts, which leads to very significant amounts of arrears to the budget of the single tax. Labor relations at enterprises in the general system of taxation are made out according to the legislation, at physical persons - businessmen insignificant number of workers can testify to large scales of unregistered work. We do not have the opportunity to even roughly analyze how many people actually work in a private individual. At the same time both in enterprises in the general taxation system, and in individual entrepreneurs part of the salary is paid informally. As a result - shadow wages and underpayment of payroll taxes to the budget. In state-owned enterprises and joint-stock companies the level of wages is higher than the national average, and in private enterprises $-70 \%$ of the average. These trends confirm the application of inter-qualification ratios in wages in stateowned enterprises and companies, and these entities have the greatest control over compliance with the law by state bodies, supervisory boards and trade union committees. Enterprises-legal entities and natural persons-entrepreneurs often set wages at the level of the minimum amount established by law, or set insignificant inter-qualification coefficients for employees of different professions, without adhering to the differentiation of wages. But by law, the minimum wage is charged to a worker who performs simple work. The lack of legal levers to regulate wage differentiation in the private sector leads to the establishment of interprofessional relations by entrepreneurs, but insufficient (7), which does not reveal differences between the qualifications of workers of different professions, reflected in low official wages and further social security of employees, promotes shadow economic activity. The use of ratios to calculate the size of salaries at the legislative level in Ukraine is regulated only for state-owned enterprises. In addition, inter-job (inter-qualification) coefficients are determined based on the tariff rate of the employee of the 1st category, which is equal to the subsistence level for able-bodied persons [8]. At the same time, the subsistence level is 2,2 times less than the statutory minimum wage. We consider reasonable the calculation of interqualification ratios in wages, based on the minimum wage. Thanks to such innovations, higher wages will be set and several times higher revenues to the country's budget will be achieved. Legislators are trying in various ways to encourage employers to set high official pay levels for employees. Thus, from January 1, 2016, the SSC rate was reduced from $36,76-49,7 \%$ to $22 \%$. As a result, entrepreneurs have taken some of the shadow wages out of the shadows. But at the same time, at the legislative level the minimum wage was increased, so the total amount of taxes paid by enterprises on wages has not changed. Thus, the scale of tax evasion, especially in sole proprietorships, remains large. The basis of state regulation of the process of de-shadowing of the national economy and violations of financial discipline should be determined by economic levers. As you know, the state budget is $80-90 \%$ formed by tax revenues, respectively, due to improved legislation to bring the economy out of the shadows, especially the activities of individual entrepreneurs, organization of inspections of enterprises, legalization of their income and ensuring payment of a significant amount of tax payments states would be much larger.

State institutions provide public economic information of poor quality - either in a veiled form or not in full. Financial indicators for the formation of budgets of all levels, payments for foreign economic activity are provided on the official website of the State Fiscal Service of Ukraine. The SFSU reports "as of" the first day of each month, without specifying the period for which the data are provided. At the same time, information on accrual is provided only for the State budget and for some taxes, and data on the actual receipt of funds are given for the Consolidated Budget in terms of all tax payments to the budgets of all levels and customs duties. Information on revenues by regions and types of economic activity is provided only on the formation of the State Budget, while the information is indicated by the total amount of actual receipts of taxes and fees without detailing them [9]. Information on accruals of local and customs payments is not provided at all. Reasons for poor data provision: instability of the political and economic situation; changes in legislation; market conditions; low level of trust in the population; instability of social conditions; level of organizational and technical activities. But the SFSU has all the data on the accrual of all taxes and fees received from tax returns received through electronic offices of enterprises, individuals - entrepreneurs and from the data on the accrual of taxes and fees directly by the tax administration to the population. In the regional departments of the state fiscal service of the country indicators from electronic tax returns of enterprises and information on tax assessments of individuals are grouped in detail by groups of taxpayers and types of tax payments. Data of state financial control should be provided in detail according to all criteria and systematized. The Statistical Civil 
Service of Ukraine provides public information in the form of the formation of statistical yearbooks in the country as a whole. Yearbooks, in which the information is provided in an expanded form - 500-600 pages - are formed unsystematically, selectively, over some years. Basically, statistical indicators are published in the form of collections, which consist of 30 pages of general data. The Statutory Office also sometimes creates and makes thematic yearbooks publicly available. Detailed information on the activities of the country and enterprises in the statistics service can be obtained only selectively and at the expense of. In this case, statistics are the main source of information in any activity for analysis and further development. Financial statements are provided by enterprises, institutions and organizations to higher branch management bodies, which carry out processing, research, make decisions based on it, all these forms of reporting are provided to the State Statistics Committee. Thus, there is a possibility of much wider disclosure of information in statistical sources. After all the purpose of the statistics department is to collect, generalize and provide information to government agencies and the population on all aspects of society.

According to the law, banking organizations publish financial statements. In this case, the report provides a large amount of information [10]. At the same time, this information extensively reveals the methodology of the organization of banking activities, but these data are needed in the internal work of the bank, in the process of management and organization. To use society in general, you need information on the types of banking products, rates, conditions of provision and service, the dynamics of banking performance, comparative characteristics with other banking institutions. This information is needed by legal entities and individuals to select the banking institutions in which they will be served, the types of banking products, the formation of views, beliefs, worldview. The creation of an effective banking system of the state depends on the conditions of its functioning. 70-75\% of assets of banking institutions are formed at the expense of attracted funds of clients - current accounts and time deposits. These funds are used to provide loans to legal entities and individuals. The amount of attracted deposits and loans in the structure of assets and liabilities of banks varies depending on the position of the banking institution in the banking market. In our opinion and according to the research of many scientists, interest rates on loans can be 1,5 times higher than interest rates on deposits, which will ensure a significant return on business, but in our country they are 2-3 times higher. The average interest rate on deposits in Ukrainian banks is $17-30 \%$. At the same time, interest rates on deposits in the world are: USA, Canada - 1\%, Great Britain $3,45 \%$, Australia - 6,3\%, Iran - 18\%, Belarus - 30\%. The average interest rate on loans in domestic banking institutions is $30-65 \%$. Loan rates in the world: USA - 2-20\%, Switzerland $-3,5 \%$, France $-4,75 \%$, Japan - 10\%, Germany $-11 \%$, Czech Republic - 22\%. The processes of attracting deposits and lending to legal entities and individuals are influenced by the following factors: instability of the political and economic situation; changes in legislation; market conditions for the provision of banking services; low inter- est rates on deposits and high lending rates; inefficiency of the deposit guarantee system; instability of social conditions; low level of trust in banks. Deposit rates should be maximum, which will attract significant amounts of funds to banking institutions. Attracting significant amounts of deposits will lead to higher working capital of banks and the establishment of much lower lending rates and increase its volume. Significant amounts of working capital of banks will ensure the development of the national banking system.

Legalization of the economy, stabilization of the country's banking system and the establishment of processes of providing economic information to society on the formation and distribution of public finances are seen as one of the main criteria for the development of the domestic economy in the global world structure.

Conclusions. The introduction in the current legislation of mechanisms of state regulation of economic activity of entrepreneurs is the main lever to bring the Ukrainian economy out of the shadows and increase gross domestic product. State control by all services to ensure the legal regulation of the economy must be carried out effectively and systematically. At the same time, it is necessary to ensure the quality of coordination of fiscal policy and balance of entrepreneurs' activities. The principle of publicity in the construction of the budget system determines the legal quality standards of public financial policy. In order to ensure transparency of budget operations, control of information and financial flows by the public, stabilization of state finances and development of the national economy, ministries and agencies must ensure quality public information, in particular the Ministry of Finance, which is responsible for the fiscal service, in general, the Cabinet of Ministers, coordinated by the Main Department of Statistics, and the National Bank of Ukraine. A much broader analysis of revenues to the Consolidated Budget should provide information in terms of all revenues by type, with information to be presented by regions of Ukraine, sectors of the economy, types of economic activity, group data by ownership, categories of payers, types of products, property, locality, groups of payers and other criteria, to the maximum extent possible, with detailed explanations. Having an efficient financial market will create conditions for the process of capital accumulation in Ukraine. The stability of the banking system is characterized by the level of working capital, the amount of which will depend on the legal protection of national financial activities. As a result of deshadowing of the economy, transparency of budget formation and distribution of public funds, stability and efficiency of the banking sector, equilibrium will be established in the country's financial system. This will provide an opportunity to organize measures for infrastructure development and contribute to the creation of a favorable environment for business activities of national producers. We emphasize that the administrative and legal levers of regulation of state revenues and expenditures are a prerequisite for national security. Improving the legislation on the organization of economic entities and state financial control in all areas will create a reliable integrated financial system of Ukraine. 


\section{LITERATURE}

1. Лагутін. В.Д. Інститути і економічні механізми стабільності та розвитку суспільства. Економіка Украӥни. 2018. № 9. C.13-25. URL: http://nbuv.gov.ua/UJRN/EkUk_2018_9_3

2. Єфименко T.I. Система управління державними фінансами України: проблеми економічної безпеки. Економіка України. 2018. № 11-12. C. 28-46. URL: http://nbuv.gov.ua/UJRN/EkUk_2018_11-12_4

3. Луніна I.О. Концептуальні засади стійкості державних фінансів. Фінанси Украӥни. 2019. № 11. С. 97-109. URL: http://nbuv.gov.ua/UJRN/Fu_2019_11_9

4. Кириленко О.П. Формування інституційного забезпечення прозорості бюджетного процесу в Україні.Фінанси України. 2017. № 8. С. 80-94. URL: http://nbuv.gov.ua/UJRN/Fu_2017_8_6

5. Богдан I.В. Фіскальні правила: проблеми імплементації в національну практику. Фінанси Украӥни. 2019. № 10. С. 3857. URL: http://nbuv.gov.ua/UJRN/Fu_2019_10_5
6. Статистичний щорічник у 2018 році: статистичний збірник. Київ: TOB “Бук-Друк”, 2019. URL: http://www.ukrstat.gov.ua/druk/publicat/kat_u/2019 /zb/11/zb_yearbook_2018.pdf

7. Праця України у 2018 році: статистичний збірник. Київ: ТОВ “Бук-Друк”, 2019. URL: http://www.ukrstat.gov.ua/druk/publicat/kat_u/2019/zb/08/zb_ pu2018_pdf.pdf

8. Закон України «Про оплату праці»: постанова ВР Украӥни № 108/95-BP від 24 березня 1995p. URL: https://zakon.rada.gov.ua/laws/show/108/95$\% \mathrm{D} 0 \% \mathrm{~B} 2 \% \mathrm{D} 1 \% 80$

9. Офіційний сайт Державної фіскальної служби України: URL: http://sfs.gov.ua/

10. Офіційний сайт ПАT «Приватбанк»: URL: https://minfin.com. ua/company/privatbank/

\section{REFERENCES}

1. Lagutin V.D. Institutions and economic mechanisms of stability and development of society. Economy of Ukraine. 2018. № 9. Pp.13-25. URL: http://nbuv.gov.ua/UJRN/EkUk_2018_9_3

2. Yefimenko T.I. System of public finance management in Ukraine: problems of economic security. Economy of Ukraine. 2018. № 11-12. Pp. 28-46. URL: http://nbuv.gov.ua/UJRN/EkUk_2018_11-12_4

3. Lunina I.O. Conceptual basics of public finance sustainability. Finance of Ukraine. 2019. № 11. Pp. 97-109. URL: http://nbuv.gov.ua/UJRN/Fu_2019_11_9

4. Kyrylenko O.P. Formation of institutional support for transparency of the budget process in Ukraine. Finance of Ukraine. 2017. № $8 . \quad$ Pp. 80-94. URL: http://nbuv.gov.ua/UJRN/Fu_2017_8_6

5. Bohdan I.V. Fiscal rules: problems of implementation in national practice. Finance of Ukraine. 2019. № 10. Pp. 38-57. URL: http://nbuv.gov.ua/UJRN/Fu_2019_10_5

6. Statistical yearbook in 2018: zbirnyk Derzhavnoi sluzhby statystyky Ukrainy. Kyiv: Buk-Druk LLC, 2019. URL: http://www.ukrstat.gov.ua/druk/publicat/kat_u/2019 /zb/11/zb_yearbook_2018.pdf

7. Labor of Ukraine in 2018: zbirnyk Derzhavnoi sluzhby statystyky Ukrainy. Kyiv: Buk-Druk LLC, 2019. URL: http://www.ukrstat.gov.ua/druk/publicat/kat_u/2019/zb/08/zb_ pu2018_pdf.pdf

8. Law of Ukraine "On Remuneration of Labor": Resolution of the Verkhovna Rada of Ukraine № 108/95-VR of March 24, 1995. URL: $\quad$ https://zakon.rada.gov.ua/laws/show/108/95$\% \mathrm{D} 0 \% \mathrm{~B} 2 \% \mathrm{D} 1 \% 80$

9. Official site of the State Fiscal Service of Ukraine: URL: http://sfs.gov.ua/

10. Official site of PJSC "Privatbank". URL: https://minfin.com. ua / company / privatbank / 


\title{
Risk management method for construction projects using a value-based approach
}

\author{
Seek Ali Mohamed Abdulsalam \\ University "KROK”, Kyiv, Ukraine \\ Corresponding author. E-mail: dimi7928@gmail.com
}

Paper received 22.05.20; Accepted for publication 15.06.20.

\section{https://doi.org/10.31174/SEND-HS2020-232VIII40-08}

\begin{abstract}
The article presents a risk management method for construction projects that are implemented using a value-based approach. Existing risk management tools are considered and analyzed. The necessity of taking into account the risks brought to the project by its stakeholders in the paradigm of value-oriented management is shown. The structure of the method and the sequence of steps for assessing and working with the risks of construction projects with value-oriented management are presented.
\end{abstract}

Keywords: risk management method, value-oriented approach, stakeholder management, risks of construction projects.

Introduction. The development of risk management tools in the construction project management industry requires the isolation, limitation and concretization of basic terminology, as well as methods and tools, from the overall risk management regulation.

Review of publications on the topic. Among the significant variety of standards and methods for risk management [1 - 7] note the following:

- standard of the Federation of European Risk Management Associations "FERMA" [1, 2];

- standard "COCO II" [1, 2];

- South African standard "KING II" [1, 2].

- standard ISO 31000:2009 "Risk Management - Principles and Guidelines" [3];

- standard IEC/FDIS 31010:2009 "Risk Management Risk Assessment Techniques" [4];

- standard ISO 73: 2009 "Risk management. Terms and definitions" [5].

The general PMBOK standard of the 6th edition [8] presents an extended concept of risk management in the project, and provides the following basic definitions.

Thus [8, p. 397] introduces the concepts of individual and aggregate project risk. In the first case, “... it is an uncertain event or condition, the occurrence of which has a positive or negative effect on one or more project objectives". The aggregate risk is positioned as the impact of uncertainty on the project as a whole, “...as a consequence of variations in project results, both positive and negative, on stakeholders".

In addition, the concept of "non-event risk" of two types is introduced [8, p. 398]:

- the risk of variability when there is uncertainty regarding certain key characteristics of an event, operation or decision foreseen by the plan;

- the risk of ambiguity when there is uncertainty about what may happen in the future. The areas of the project in which incomplete knowledge may affect the ability to achieve the objectives of the project include: elements of requirements or technical solutions; future regulatory development; system complexity inherent in the project.

The author [9] notes that "... the terms "uncertainty", "decision-making", "risk" and "danger" should constitute an integral terminological system".

In article [9], the author gives the following definitions to the indicated terms: "Uncertainty is a state of a person, determined by his system of knowledge in a specific situation of an objectively uncertain environment regarding the impossibility / possibility of deciding on further activities in case of incomplete and unclear perception of the situation, his insufficient awareness and uncertainty in necessary actions associated with future events, their impact on activities and implications for expected values (planned result)".

"Risk is a state of activity of the management object, which is realized in the conditions of uncertainty when manifestation of events (quantitatively taken into account and not taken into account at decision-making about activity) which can lead primarily to negative deviations from achievement of expected value (planned result) is possible".

The authors [10, p. 137-138] determine the uncertainty in the construction project and its risks, as follows. Uncertainty is ".. incompleteness or incorrectness of information about the conditions of the project, including information about possible costs and the corresponding results of the actual implementation of the project".

The authors associate uncertainty with the external environment (economic, political, social, etc.) and the set of variables that must be taken into account in the process of project development.

The reasons for uncertainty in construction projects are indicated [10]:

- spontaneity of natural processes and phenomena, natural disasters;

- coincidence, when under similar conditions, the same event occurs differently as a result of many socioeconomic and technological processes;

- presence of conflicting tendencies and interests;

- incompleteness, lack of information about the object, process, phenomenon;

- limited information on the rhythm of providing material, financial, labor and other resources in the process of project implementation.

Project risks are comprehended [10] as an action in the decision-making process on the feasibility of development and implementation of the project to achieve the aim, taking into account possible changes in the conditions of its implementation, the occurrence of adverse circumstances and related consequences of losses, damages.

The authors of [10] measure the magnitude of the risks "... by the probability of the occurrence of a particular event, which can lead to losses in the process of project implementation. Probability is determined by statistical or subjective methods. According to the sources of occur- 